For citation: Ali M. M., Rattanawiboonsom V., Perez C. M., Khan A. A. (2017). Comparative Positioning of SMEs in Bangladesh, Thailand and the Philippines. Ekonomika regiona [Economy of Region], 13(2), pp. 381-395 doi 10.17059/2017-2-5

UDC: 332

JEL: D22, G21, G23, 016

M. M. Ali ${ }^{\text {a) }}$, V. Rattanawiboonsom ${ }^{\text {b) }}$, C. M. Perez ${ }^{\text {c) }}$, A. A. Khan ${ }^{\text {d) }}$

a) Dhaka School of Economics (Dhaka, Bangladesh.e-mail:pipulbd@gmail.com)

b) Naresuan University (Phitsanuloke, Thailand)

c) Philippines University (Laguna, Philippines)

d) Khulna University (Khulna, Bangladesh)

\title{
COMPARATIVE POSITIONING OF SMALL AND MEDIUM ENTERPRISES IN BANGLADESH, THAILAND AND THE PHILIPPINES
}

Small and Medium Enterprises (SMEs) play a significant role in the nation's economic development process. SMEs provide job opportunities, create wealth, promote modernization and contribute to technological changes. The Asia-Pacific Region is foreseen to be the next economic boom. A comparison of SMEs in Bangladesh, Thailand and the Philippines on their SMEs Landscape, Banking sector, Non-Banking sector and Capital Markets would give a picture of which strengths, weaknesses, opportunities and threats these countries face. The time period of the study is from August 2016 to January 2017. Based on the secondary sources of data, the research was conducted to examine real scenarios. The study aimed at getting information whether each country would have any benchmark to attain the best practices. The study found that $S M E s$ credit and repayment schemes in these countries need to be gradually improved. Through proper utilization of SMEs, these countries can alleviate poverty and attain economic progress. Unfortunately, the informal sector of these countries is playing a large role. It should be transformed to formal sector by financial inclusion. This can be achieved by setting up SMEs in the formal sector.The creation of employment along with poverty reduction in the formal sector will enhance economic growth as well as fulfill the basic needs and create empowerment of people. Community banking is suggested to be introduced for accumulating micro-savings and allocating, distributing setting up SMEs in the formal sector through micro investment under the umbrella of community banking. Further, under the regional cooperation flagship of Bengal Initiative for Multi-Sectoral Technical and Economic Cooperation (BIMSTEC) Bangladesh and Thailand may work in collaborative manner in the SMEs sector. The Philippines may join the regional body of BIMSTEC and collaborate with SMEs at the regional level. This may lead to achieve some goals of sustainable development goals (SDGs). SMEs can work more rigorously for lower income group people to improve their living standard. The further research on these three countries can consider primary sources of data to find out the way to implement community bank for transforming micro savings to micro investment for removing income inequality, disparity and attaining social justice.

Keywords: Bangladesh, Banking Sector, Community banking, Capital Market, Economic Boom, Income, Philippine, Poverty, SMEs, SDGs, Thailand, Trade

\section{Introduction}

Nowadays, Small and Medium Enterprises (SMEs) play a vital role for the economic development for both its formal and informal sector. The rise of a portion of the formal sector is relatively desirable for a country. The existence of SMEs is necessary for a nation's economic development, job creation and innovation. ${ }^{2}$ It serves as the backbone of the national economies in

\footnotetext{
1 @ $\mathrm{Ali}$ M. M., Rattanawiboonsom V., Perez C. M., Khan A. A. Text. 2017.

${ }^{2}$ Retrieved from: https://www.gpfi.org/sites/default/files/documents/SME\%20Finance\%20Forum\%20Report\%202014-Final. pdf (date of access: 1st of October, 2016).
}

the Asia-Pacific countries in a global economic uncertainty. ${ }^{34}$ Nowadays, not only in the informal sector but also in the formal sector, the importance of SMEs is understood. In Asia (20072012), SMEs contributed an average of $38 \%$ of Gross Domestic Product or Manufacturing Value, and influenced export trade by $30 \%$. Further, it accounts an average of $98 \%$ of all enterprises and $66 \%$ of the national labor on the average. SMEs have become a part of the global supply chain

\footnotetext{
${ }^{3}$ Asian Development Bank, Asian. (2014 a). SME Finance Monitor 2013. Asian Development Bank.

${ }^{4}$ Asia Development Bank. (2015). Asia, SME Finance Monitor 2014. Asian Development Bank.
} 


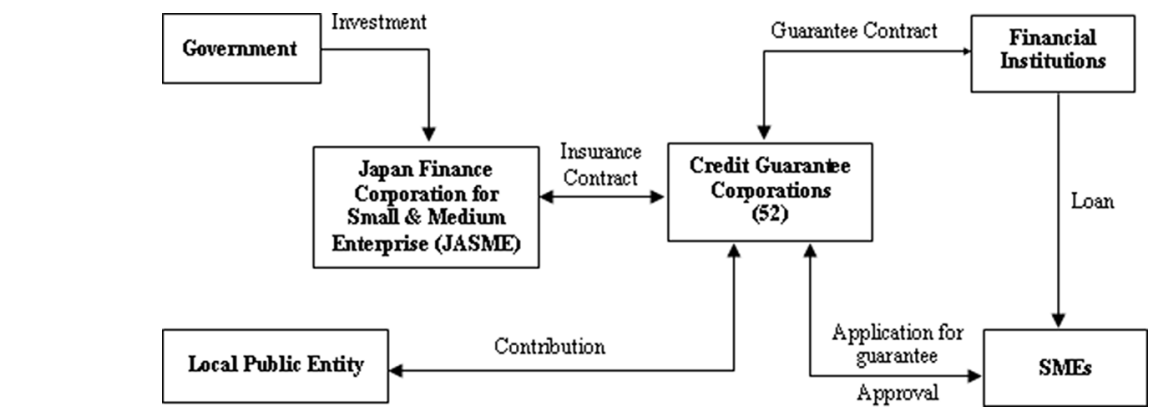

Fig. 1. Credit Supplementation System for SMEs.

Source: http://www.chusho.meti.go.jp/sme_english/outline/04/01_01.html (Date of access 2 May, 2017)

that has the potential to promote international trade and mobilize domestic demand [1]. SMEs simply are business establishments ranging from micro, small and medium enterprises engaged in different entrepreneur activities that are defined specifically by the countries concerned. The Asia SME Finance Monitor are classified into five criteria by law, a number of employees, net or total assets, annual turnover and capital invested and through sector wise [1, 2, 3]. In Figure 1, we have shown Credit Supplementation System for SMEs in Japan.

In Figure 1, we have seen the credit supplement relationship at Japan. Government is playing a vital role for investment purposes .In Bangladesh, Thailand and Philippine have their own organization to expedite the SME businesses. On the other hand financial institutions play critical role for those who have the access to the financial intermediaries. But if they do not have access then the rate of interest is high. However, Bangladesh does not have credit guarantee cooperation.. However, in above noted countries mostly SMEs work under informal sector and relatively working under formal sector is very low. Contribution is also occurred at local public entity in Japan which is less in these countries. However, SMEs in these countries and beneficiaries are rising gradually. Infrastructure is related to the institutional mechanism. This is supported by knowledge and public resources which are related to technology uncertainty. The institutional mechanism is related to industry illegitimacy. Proprietary resources are related to Entrepreneurship-liability of Newness. Knowledge spillover and commercialization help to expedite the process of SMEs. Commercialization is the procedure, which is acquainting with an innovative creation or assembly technique keen to doing business. Industry interaction and market structure create a scope for doing business which is interrelated to producer and consumer and is focused by financier. Market perfection creates an advantageous situation for both buyer and seller.
Bangladesh defined its SMEs based on the value of fixed assets (excluding land and building), and/or on the number of employees including the sector it belongs. Cottage and micro industries were also defined for greater financial inclusion. Manufacturing, service and trade firms with fixed assets of less than USD .006 million and 10 or fewer employees (including family members) are considered to be cottage enterprises. Manufacturing firms with fixed assets of USD .006 million - USD .06 million and 10-24 employees, and service and trade firms with fixed assets of less than USD .006 million and less than 10 employees are considered to be micro enterprises. Manufacturing firms with fixed assets of USD .06 million - USD 1.2 million and 25-99 employees, and service and trade firms with fixed assets of USD .06 million - USD .12 million and 10-25 employees, are considered to be small enterprises. Manufacturing firms with fixed assets of USD 1.2 million - USD 3.6 million and 100-250 employees, and service and trade firms with fixed assets of USD 0.12 million - USD 1.8 million and 26-100 employees are considered to be medium-sized enterprises. ${ }^{1}$

Thailand defines SMEs based on the value of fixed assets, the number of employees, the sector it belongs and how the Ministry of Industry defines. The SME definition differs by sector; for instance, firms having less than 200 employees and net assets of USD 5.8 million are regarded as SMEs of the manufacturing and service sectors. For SME lending, the Bank of Thailand guides financial institutions to follow this national SME definition, but they have often used their own definitions for operations.

The Philippines defines SMEs as entrepreneurial firms in the category as micro, small, and medium-sized enterprises with total assets (excluding land) of USD 2 million or less. However, when it pertains to guiding financial institutions, the

\footnotetext{
${ }^{1}$ Asian Development Bank. (2014b). ADB-OECD study on enhancing financial accessibility for SMEs: Lessons from recent crises, Philippines.
} 
use of the legislated definition is applied. The Bank of the Philippine Islands provides sustainable energy finance for SMEs in the Philippines. Maximum potential award (in US\$) Disbursement as of December 2014 (in US\$) was 1,240,57 while Disbursement as of December 2014 (in US\$) was $2,744,343$ and status was Completed/Goals met. ${ }^{1}$

Bangladesh SMEs accounted for more than $99 \%$ of private sector industrial establishments and created job opportunities ranging from $70 \%$ to $80 \%$ of nonagricultural labor force. The share of SMEs' production value added to the gross domestic product (GDP) ranged between $28 \%$ and $30 \%$ aside from the significant contributions to national exports. ${ }^{2}$

Thailand reported 2.7 million small and medium-sized enterprises (SMEs) in 2012, accounting for $98.5 \%$ of total enterprises. Trade (wholesale, retail trade, and automotive repair), manufacturing, and service (e.g., hotels and restaurants) is the dominant sectors in number, employment, and contribution to gross domestic product (GDP). In 2012, SMEs accounted for $37.0 \%$ of GDP and $80.4 \%$ of the workforce.

Thai SMEs also have a positive influence on international trade, contributing to $28.8 \%$ of total exports and $31.9 \%$ of total imports in value. The SME export and import industries achieved a V-shaped recovery from the 2008/09 global financial crisis, but the flooding in 2011 slowed down both imports (growth of $3.7 \%$ in 2012) and exports (3.5 \%). SME exports are smaller than imports in scale, and the gap between them has been increasing. In 2011, the Philippines got 816,759 number of registered Philippine SMEs representing $99.6 \%$ of total enterprises; $47.0 \%$ of the MSMEs (Micro, Small, medium enterprises) are in the trade and repair (wholesale and retail trade and repair of motor vehicles and motorcycles) sector, followed by services with $38.5 \%$. The service sector had the largest SME contribution to employment at $46.1 \%$ of total SMEs employment, while trade and repair accounted for $33.9 \%$ in $2011 .{ }^{3}$

Bangladesh, Thailand and the Philippines are three growing economies in the Asia-Pacific Arena. In 2012, there were 2.7 million of SMEs in Thailand comprising $98.5 \%$ of total enterprises. In the same year, SMEs accounted for $37.0 \%$ of GDP

\footnotetext{
${ }^{1}$ Retrieved from: https://www.gpfi.org/sites/default/files/documents/SME\%20Finance\%20Forum\%20Report\%202014-Final. pdf(date of access: 1st October, 2016).

2 Asian Development Bank, Asian. (2014 a). SME Finance Monitor 2013. Asian Development Bank.

${ }^{3}$ Asian Development Bank. (2014b). ADB-OECD study on enhancing financial accessibility for SMEs:

Lessons from recent crises, Philippines.
}

and $80.4 \%$ of the workforce. Thai SMEs also contributed to $28.8 \%$ of total exports and $31.9 \%$ of total imports by value in $2012 .{ }^{4}$ In the Philippines, SMEs account for $99.6 \%$ of total registered enterprises. Out of the 820,255 businessmen which operated in the country, 816,759 were SMEs while only 3,496 were large enterprises. Of these, $91 \%$ $(743,250)$ were microenterprises, $8.6 \%(70,222)$ comprised of small firms, and less than one percent $(3,287)$ made up medium-sized companies. In 2011, the Philippine SMEs also accounted for $32 \%$ of the country's GDP. ${ }^{5}$ In Bangladesh, SMEs share about $90 \%$ of private sector enterprises and 70$80 \%$ of non-agricultural workforce. In the years of 2015-16, the contribution of industries (manufacturing) was 20.77, of which large- and medium-scale industries contributed $17.19 \%$, and small industries $-3.58 \%$. Over the last ten years, the contribution of small industries remained almost the same. It was $3.22 \%$ in 2005-06, meaning that it increased only by $0.36 \%$ during the period. While in the case of large and medium industries, it increased by $4.27 \% .{ }^{6}$ But maximum SMEs in Bangladesh is working in informal sector.

SMEs definition depends on the officials of multilateral development institutions within their individual context as presented in Table 1.

Definition of SMEs varies from one institution to another institution and country to country.

Now, we are describing the model of SME service branding below (see Figure 2).

From Figure 2, we observe how SMEs service branding can work. It is related to diversified forces starting from Management and Staff, brand equity, desire to succeed, the influence of owner/ manager on change, procrastination to customers. Communication and budget restrictions are significantly related but it has negative relationship. Here, nucleases are SME service branding. As such SMEs may work at manufacturing, on-farm activities, or service sector but the branding of service is important.

Our research question is why and how SMEs play important role in these three countries and whether the joint collaborative effort will give better results?

The researchers aimed to compare three different countries on how their SMEs performed? The

\footnotetext{
${ }^{4}$ Retrieved from: http://www.asiapathways-adbi.org/2015/07/ importance-of-smes-in-the-thai-economy/ (date of access: 1st March,2017).

Retrieved from: http://www.philstar.com/business-usual/2014/01/20/1280682/smes-seen-major-economicgrowth-driver(date of access: 1st March,2017).

6 Retrieved from: http://print.thefinancialexpress-bd. com/2016/11/08/156069/print(date of access: 1st March,2017).
} 
Table 1

SME Definitions Used by Multilateral Institutions

\begin{tabular}{|l|c|c|c|}
\hline \multirow{2}{*}{\multicolumn{1}{|c|}{ Institution }} & \multicolumn{2}{c|}{ Max. Revenues } \\
\cline { 2 - 4 } & Maximum \# of Employees & Or Turnover (\$) & Maximum Assets (\$) \\
\hline World Bank & 300 & $15,000,000$ & $15,000,000$ \\
\hline MIF-IADB & 100 & $3,000,000$ & (none) \\
\hline African Development Bank & 50 & (none) & (none) \\
\hline Asian Development Bank & No official definition. Uses only definitions of individual national governments \\
\hline UNDP & 200 & (none) & (none) \\
\hline
\end{tabular}

Source: [3].

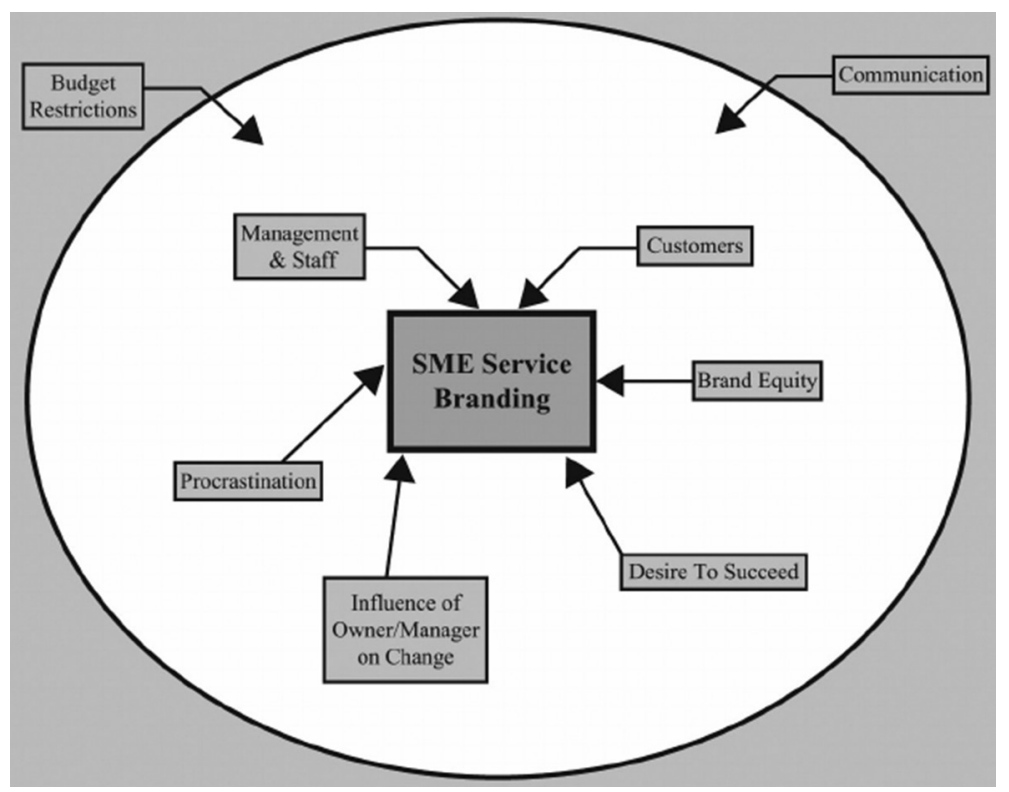

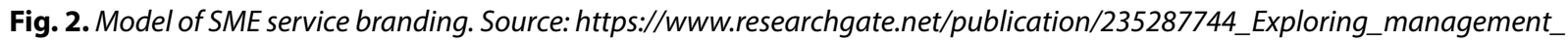
perspectives_of_branding_in_service_SMEs/figures?lo=1 (date of access: 1st February 2017)

study also intended to discuss both financial and policy issues as both are interrelated. We shall also provide some findings, implications as well as direction for future study.

\section{Literature Review}

Legitimate considerations of the different levels of poverty and relative competition among private enterprises should be considered as part of the definition of SMEs [3]. The government of Bangladesh has to adequately distribute its resources through different budgetary measures to different sectors, preferably to SME-related and employment-enhancing activities. Considering the extent of importance of various sectors, priority is usually given to some important sectors, such as RMG, agriculture, livestock, agro-based industries, textiles, jute industry and so on [4]. Governments support and intervention was necessary to promote SMEs in both developing and industrialized countries. Their SME assistance strategies often try to achieve a combination of equity objectives (alleviating poverty and addressing social, ethnic, and gender inequalities) and ef- ficiency objectives (raising the productivity and profitability of firms). However, authors further stated that the confusion created by Government's multiple objectives often leads to over-subsidize services that could be provided by the market. The direct provision of credit and non-financial assistance to SMEs tends to substitute for markets rather than dealing with the underlying causes of market underdevelopment [5]. The background factors like strong education and training facilities, desire to achieve, accept responsibility, hard work and risk orientation of an entrepreneur have a bearing on the success of entrepreneurs. In addition to this, the socio-economic factors such as uniform commercial law and limited regulations, corruption, encouragement and support from society and family, good banking with available credit, social integration, social status, meaningful democracy, and free trade with limited tariffs, enterprise zone, available technology, and strong telecommunication and distribution networks are also important for creating entrepreneurs [6].

Thai SMEs in the new competitive environment was struggling with problems that decrease 
their ability to compete in international markets12 SMEs tried to raise economic productivity and benefits through changing the traditional role as well as increasing competitiveness in the global economic process [7]. An entrepreneurship development programme consisted of the following three phases: Initial or pre-training phase; Training or development phase; Post-training phase [8]. Thai SME's faced following problems in boarder aspects: First is a declining competitiveness; second is a limited access to capital; third is a lack of entrepreneurship; fourth is poor state management in SME promotion [9]. SMEs play a key role in economic development and important contribution to employment. Financial access is critical for SME growth and development as the availability of external finance is positively associated with productivity and growth. Further, World Bank concluded that more work is needed to evaluate the wide variety of SME finance policies, and international organizations are well suited to fill in these knowledge gaps. ${ }^{1}$ Increasing bank efficiency is a commonly shared problem in Asian and Organization for Economic Co-operation and Development (OECD) countries, although the problem is acuter in Asia. Nevertheless, both areas present the challenge of improving the instruments and enhancing the supply of bank options for SMEs. ${ }^{2}$ More than nine-tenth $(91.3 \%$ ) of the non-governmental organizations (NGOs) which are partner organizations of Bangladesh NGO Foundation help in developing women entrepreneurship. It has been seen that there is a significant association between NGOs role for discovery and productivity and giving the right training/ education [10]. Individual characteristics might play a greater role in determining the process of how (rather than if) entrepreneurial entry occurs, and that the process of how entrepreneurial entry transpires has important implications for new business survival [11].

As SMEs develop, each entrepreneur needs to establish both a moral and a professional support network. These contacts provide confidence, support, advice and information [12]. However, bank support was not accompanied by adequate and efficient entrepreneurial guidance, supervision and direction [13]. The rural sector is characterized by a high degree of underemployment and low pro-

\footnotetext{
${ }^{1}$ World Bank. (2012, October). Impact Assessment Framework: SME Finance, Prepared by the World Bank on behalf of the G20 Global Partnership for Financial Inclusion (GPFI) SME Finance Sub-Group, 7-33.

${ }^{2}$ Asian Development Bank. (2014b). ADB-OECD study on enhancing financial accessibility for SMEs: Lessons from recent crises. Philippines
}

ductivity. Increased public investment in rural infrastructure and provision of extension services are vital for raising productivity in agriculture. A rise in productivity in the farm will also benefit the non-farm rural economy. ${ }^{3}$

In the Philippines, there is a Bureau of Small and Medium Enterprise Development (BSMED), which is under the Department of Trade and Industry (DTI), but this bureau does not have an all-encompassing mandate. In Thailand, linking up SMEs with large corporations is an important component of the country's policy to strengthen its supporting industries. In 1992, the government established the BOI Unit for Industrial Linkage Development (BUILD) to take charge of industrial linkage development. BUILD acts as «an intermediary between manufacturers of ready-made products and small-and medium-sized manufacturers of parts, which will result in the linkage of industries and the transfer of production technology» (BUILD, undated). The objectives of BUILD are: (a) to promote the establishment of an industrial linkage network by strengthening the relationship between assemblers and parts suppliers; (b) to promote the development of supporting industries, which will enhance the competitiveness of assemblers in Thailand; (c) to help small-and medium-sized manufacturers of parts increase production efficiency and product quality; (d) to promote cooperation between foreign investors, Thai parts manufacturers, and government offices; (e) to promote Thailand as the region's center for parts manufacturing and source of raw materials; and (f) to eliminate obstacles in subcontracting and to push for policy changes that will facilitate industrial linkage development [14]. Formal sector subcontracting is positively related to employment growth only in the most modern segments of the informal sector. They argued that subcontracting can contribute to job creation in relatively modern segments of the informal sector [15].

The analysis of overall financial inclusion indicates that financial inclusion has been increasing since 2009 in Bangladesh. Financial inclusion as a percent of total adults' population by banks increased to $66.7 \%$ in 2014 from $42.2 \%$ in 2009. The same by MFIs increased to $32.7 \%$ in 2014 from $22.4 \%$ from 2004 in Bangladesh [15]. While the Philippines are at the forefront of promoting and creating an enabling environment for financial inclusion, some sector experts believe that delivery and implementation are weak. In an archi-

\footnotetext{
${ }^{3}$ Yap, J. T. et al. (2009). Impact of the Global Financial and Economic Crisis on the Philippines. Philippine Institute for Development Studies, Discussion Paper Series No. 30(date of access: 1st October, 2016).
} 
pelago made up of more than 7,000 islands, there are huge financial, security and logistical challenges in reaching the poor and unbanked. The concentration of micro finance institutions (MFIs) is found in the urban and semi-urban areas with larger populations, and this often results in lenders charging higher interest rates. The market for financial services to the low-income population in Thailand is immature and there are regulations that make it unattractive for financial providers to enter the microfinance sector, most notably the interest-rate caps that make it difficult to cover the cost and risk of doing so. ${ }^{1}$

The SMEs financing in the industry sector should take priority over other sectors of the business. Creation of industry under environment-friendly atmospheres will help to achieve the target of creating employment opportunities [16]. Addressed some of the most pervasive nature of myths related to small business performance in an engaging manner, capturing the nuances were not actually real [17]. The research identified five types of innovation: product; Process; Ways of organizing business operations; Marketing; New markets [18]. Asian policy-makers should develop regulations that will promote an efficient, financially inclusive and stable financial system that supports the growth of their evolving real economies. [19]. The study evaluated creation and configuration of the contextual infrastructure necessary for nascent technology entrepreneurship in new industries. It shows of how the elements of infrastructure are emerged and configured through systemic evolution. The data highlight how boundary crossing and obfuscation induces the configuration of separate elements into a cohesive infrastructure through heightened interaction and interdependence of organizations and institutions, both private and public [20]. The alternative paradigm of sustainable development based on equity economic growth and environmental protection with the human being placed at the center of the stage would purposefully respond to the realities both internal and external, faced by a country like Bangladesh [21]. The combination of the role of organizational culture under a new construct International Entrepreneurial Culture (IEC), with a particular emphasis on how cultural values embedded in organizational cultures dimensions significantly affects strategy formulation and strategy implementation in a conse-

\footnotetext{
${ }^{1}$ Islam, Md. Ezazul (2015). Inclusive Finance in the Asia-Pacific Region: Trends and Approaches. Draft discussion paper submitted to Asia-Pacific High-Level Consultation on Financing for Development meeting. Jakarta, Indonesia, 29-30 April (date of access: 1st October, 2016).
}

quential manner, although it is not directly influence in international performance. The findings offer a theoretical contribution to the international entrepreneurship literature as well as managerial implications for policy makers dealing with SMEs in Thailand in small open economies found in emerging markets [22]. SMEs need to harness their Knowledge Management (KM) orientation in order to leverage the knowledge-based resources emanating from their relational capital towards building their innovation capability. This capability is essential in integrating effective environmental management practices in business. The study underscored the need of developing an organizational capability to engage in KM in order to adopt sustainable business practices [23].

We have observed that the most of the studies are relatively based on a single country or on the area of different countries which author(s) found suitable but no comparison between Bangladesh, Thailand and the Philippines. Moreover, we have observed that though Bangladesh and Thailand both are members of BIMSTEC-regional cooperation association but there is no comparative study on SMEs sector. Further, we also want to include how the Philippine SMEs work, which will not be clear without comparative study. If Philippine joins in BIMSTEC as a member country whether it will have any collaborative effort at SME sector?

\section{Methodology of the Study}

In the study, secondary sources of data were undertaken from Bangladesh, Thailand and the Philippines have been used. Exact sources were mentioned. Other related literature from different sources has been also applied to derive implications and methodology. The comparison of each individual's strengths, weaknesses, opportunities and threats has been used to arrive at conclusions and implications including future direction of the research. The authors also would like to see whether SDG 1, SDG 5 and SDG 8 can be attained through creating SMEs in a collaborative effort. The time period of the study is August 2016 to January 2017. The study is based on qualitative analysis.

\section{Analysis of the Findings}

\section{SME Landscape}

On the assessment of SME Landscape of the Bangladesh, the Philippines and Thailand (Table 2 ), each country has the means of classifying the type of enterprise. The Philippines and Thailand have similar data. All countries had a high percentage of SMEs to total enterprises. Any support 
SME Landscape (based on available data 2012-2014)

\begin{tabular}{|l|c|c|c|}
\hline & Bangladesh & Philippines & Thailand \\
\hline Total \% SMEs & $90 \%$ to $99 \%$ & $99.60 \%$ & $97.20 \%$ \\
\hline \multicolumn{2}{|c|}{ Type of enterprise } \\
\hline Trade and F & no data & $46.4 \%$ & $27.7 \%$ \\
\hline Service & no data & $39.4 \%$ & $34.8 \%$ \\
\hline Manufacture & no data & $12.5 \%$ & $29.6 \%$ \\
\hline Agriculture & no data & $0.9 \%$ & - \\
\hline \multicolumn{4}{|c|}{ Alternative data for Bangladesh: $($ millions $)$} \\
\hline Permenent & 4.5 & - & - \\
\hline Temporary & 0.5 & - & - \\
\hline Non agriculural & 3.0 & - & - \\
\hline Total Estimation & 8.0 & - & \\
\hline
\end{tabular}

Source: Asia Development Bank. (2015). Asia. SME Finance Monitor 2014. Asian Development Bank.

Table 3

SME Policies and Financial Regulations - SME Promotions

\begin{tabular}{|l|l|l|l|}
\hline & \multicolumn{1}{|c|}{ Bangladesh } & \multicolumn{1}{|c|}{ Philippines } & \multicolumn{1}{c|}{ Thailand } \\
\hline $\begin{array}{l}\text { Regulator } \\
\text { and Policy } \\
\text { Maker }\end{array}$ & $\begin{array}{l}\text { (1) National SME Task } \\
\text { Force \& (2) Ministry of } \\
\text { Industry }\end{array}$ & $\begin{array}{l}\text { (1) Department of Trade } \\
\text { \& Industry \& Micro. (2) } \\
\text { Small \& Medium Enterprise } \\
\text { Development Council }\end{array}$ & $\begin{array}{l}\text { (1) Office of Small and Medium Enterprises } \\
\text { Promotion (OSMEP). (2) Ministry of } \\
\text { Industry. (3) National Board of SMEs } \\
\text { Promotion }\end{array}$ \\
\hline Regulation & none & $\begin{array}{l}\text { Magna Carta for Micro, Small } \\
\text { and Medium Enterprises } \\
\text { (RA6977 of 1991). Amended } \\
\text { RA8289 of 1997. and } \\
\text { Amended RA9501 of 2008 }\end{array}$ & $\begin{array}{l}\text { (1) SME Promotions Act BE 2543 (2000), (2) } \\
\text { Ministerial Regulations BE2545 (2000) }\end{array}$ \\
\hline Policies & $\begin{array}{l}\text { (1)Industrial Policies } \\
\text { (2005-2010). (2) Policies } \\
\text { Development of SMEs } \\
\text { (2005). (3) Small and } \\
\text { medium enterprises credit } \\
\text { policies and programs } \\
\text { (2010) }\end{array}$ & $\begin{array}{l}\text { (1) Small and Medium } \\
\text { Enterprise Development Plan } \\
\text { (2004 -2010). (2) Micro, Small } \\
\text { and Medium Development } \\
\text { Plan (2011-2016). (3) } \\
\text { Philippine development Plan } \\
\text { (2011-2016) }\end{array}$ & $\begin{array}{l}\text { (1) The First SME Promotional Plan (2002- } \\
\text { 2006). (2) The Second SME Promotional Plan } \\
\text { Plan (2012-2016). (4) SME Promotional } \\
\text { Strategic Plan and Action Plan by Sector } \\
\text { (2013). (5) Thailand Country Strategy (2012). } \\
\text { (6)Five year strategic Plan (central bank) 2012 }\end{array}$ \\
\hline
\end{tabular}

Source: Asia Development Bank. (2015). Asia. SME Finance Monitor 2014. Asian Development Bank.

and improvement provided or assisted to SMEs would have a big impact on the development of each nation's economic stature.

Having a common data would be helpful to derive a clearer analysis and projection of possible opportunities. As seen globally, Asian countries are being tapped as Business Process Outsourcing (BPOs) due to cheaper and more efficient service. These services currently have been seen in both the Philippines and Thailand (Huang 2013) as an increasing opportunity. ${ }^{1}$ In Bangladesh, Business Process Outsourcing does not have concrete data but in India, a country close to Bangladesh, is one of the leading countries in BPOs. On the area of SME Promotions (Table 3), Bangladesh and the

\footnotetext{
${ }^{1}$ Huang, R. (2013). Thailand Contact Center Industry on the Rise, ZDNet. February 12. Retrieved from: http://www.zdnet. com/article/thailand-contact-center-industry-on-the-rise/2016 (date of access: 1st October,2016).
}

Philippines have minimum two regulators while Thailand has three regulators. This is good as it would necessitate responsibility and accountability of an institution responsible for SMEs continuous growth. Entrepreneurs would be encouraged to build and develop their competencies in their selected field of endeavors.

On the Regulation issue, a passed law is seen in both the Philippines and Thailand to support such promotions but in Bangladesh this sort of support to promote SMEs are lacking though govt. established SME foundation. The law would give a clear direction on what agency would finally implement such actions as well as who should plan it. Each agency would provide a coordinating effect while avoiding duplication. Any future policies that would be based on a regulation created by the legislative branch of government can ensure continuity of common goal and objective. 
Table 4

SME Policies and Financial Regulations - Non Banking Sector

\begin{tabular}{|l|l|l|l|}
\hline & \multicolumn{1}{|c|}{ Bangladesh } & \multicolumn{1}{c|}{ Philippines } & \multicolumn{1}{c|}{ Thailand } \\
\hline $\begin{array}{l}\text { Regulator } \\
\text { and Policy } \\
\text { Maker }\end{array}$ & $\begin{array}{l}\text { Micro Credit Regulatory } \\
\text { Authority (MFIs) }\end{array}$ & $\begin{array}{l}\text { Cooperative Development } \\
\text { Authority }\end{array}$ & none but Bank of Thailand regulates \\
\hline Regulation & $\begin{array}{l}\text { Micro Credit Regulatory } \\
\text { Authority Act no. } \\
\text { 32/2006 }\end{array}$ & Cooperative Code & $\begin{array}{l}\text { (1) Financial Institution Business Act BE } \\
\text { 2551(2008), (2)SME Development Bank of } \\
\text { Thailand Act BE 2545 (2002), (3)Small industry } \\
\text { Credit Guarantee Corporation Act BE 2534 } \\
\text { (1991), (4) Credit information Business Act BE } \\
\text { 2545(2002), (Amendments in 2006 and 2008) (5) } \\
\text { Business Security Act (draft) }\end{array}$ \\
\hline Policies & $\begin{array}{l}\text { (1)Industrial Policies } \\
\text { 2005-2010) (2) Policies } \\
\text { and Strategies for } \\
\text { Development of SMEs } \\
\text { (2005) (3) Small and } \\
\text { medium enterprises } \\
\text { credit policies }\end{array}$ & $\begin{array}{l}\text { (I) Small and Medium } \\
\text { Enterprise Development Plan } \\
\text { (2004 -2010) (2) Micro, Small } \\
\text { and Medium Development } \\
\text { Plan (2011-2016) } \\
\text { (3) Philippine development } \\
\text { Plan (2011-2016) }\end{array}$ & $\begin{array}{l}\text { (1) The First SME Promotional Plan (2002- } \\
\text { 2006), (2) The Second SME Promotional Plan } \\
\text { (2007) 2011), (3)The third SME Promotional } \\
\text { Ptrategic Plan and Action Plan by Sector (2013), } \\
\text { (5)Thailand Country Strategy (2012), (6)Five } \\
\text { year strategic Plan (central bank) 2012 }\end{array}$ \\
\hline
\end{tabular}

Source: Asia Development Bank. (2015). Asia. SME Finance Monitor 2014. Asian Development Bank.

Further, the List of Policies of both the Philippines and Thailand contemplates that there is a progression of attainment of goals from one policy to another. It covers a plan of development for a particular period of time with a set of targeted objectives. Any unattained objective and new pressing needs could be updated within the new policy. A system of continuous improvement is developed and maintained. Any new threats and opportunities are addressed by adopting a revised version of the past policy. This would match with any foreseen strengths and weakness that had been observed during the past policy.

In Bangladesh, however, there are different policies that have been created in a global sense like industrial policies but specific on the development of SMEs and credit policies and programs of SMEs. It ventures out to address the needed policy for the current demands of the business industry.

In the Philippines as well as Thailand, there is a specific regulation assigned for each type of financial institution. This regulation would specify the industries current needs and make specific refinements on each type of delivering institutions. More specific, more directed and related services are placed into one law. These laws would be beneficial to have its operating policies consolidated into a policy or each particular financial institution.

On SMEs Policies and Financial Regulations -Non-Banking Sector (Table 4), it could be seen that Bangladesh and the Philippines do have a specific institution for the development of Policy different from a Banking Sector. This is important since the needs of the non-banking sector would have more focus as compared with an institution dealing with both banking and non-banking sector. The non-banking specific needs could be harnessed and set.

In Bangladesh and the Philippines, it could be seen that there are laws which was established to regulate the non-banking financial institutions.

Though in Bangladesh, the establishment of Micro Credit Regulatory Authority expected to prevent the operation of usurious acts of having very high-interest rates to individual borrowers but in reality still interest rate is around 30-49\%. As such intended to monitor and control the operations and regulate the existence of these micro credit establishments were not feasible. However, currently, Micro Credit Regulatory Authority departures from its own vision and mission and they are not at all facilitating micro credits growth. Rather Bangladesh NGO foundations are playing in a limited scale to create micro entrepreneurs in Bangladesh. Neither Grammen Bank nor Social businesses in Bangladesh are trying to remove poverty rather than keeping pauper under lowlevel equilibrium trap. Grameen Bank's current operational model is old fashioned and it is not functioning properly. Rather Comilla Cooperative model is more workable if nepotism, corruption and mismanagement can be driven out.

On the other hand, the Cooperative Code of the Philippines is intended to develop self-sufficiency among credit associations. This would assist each individual member basic (food and education), personal (acquisition of personal appliances and gadgets) and investment needs (business and savings). 
SME Policies and Financial Regulations - Capital Markets

\begin{tabular}{|l|l|l|l|}
\hline & \multicolumn{1}{|c|}{ Bangladesh } & \multicolumn{1}{c|}{ Philippines } & \multicolumn{1}{c|}{ Thailand } \\
\hline $\begin{array}{l}\text { Regulator } \\
\text { and Policy } \\
\text { Maker }\end{array}$ & $\begin{array}{l}\text { Security and Exchange } \\
\text { Commission \& Ministry } \\
\text { of Finance }\end{array}$ & $\begin{array}{l}\text { Security and Exchange } \\
\text { Commission }\end{array}$ & Security and Exchange Commission \\
\hline Regulation & $\begin{array}{l}\text { Security \& Exchange } \\
\text { Ordinance no. XVII.1969 }\end{array}$ & $\begin{array}{l}\text { Securities Regulation Code } \\
\text { (RA8789) }\end{array}$ & Security and exchange Act BE2536 (1992) \\
\hline Policies & $\begin{array}{l}\text { (1)Industrial Policies } \\
\text { (2005-2010) (2) Policies } \\
\text { and Strategies for } \\
\text { Development of SMEs } \\
\text { (2005) (3) Small and } \\
\text { medium enterprises credit } \\
\text { policies }\end{array}$ & $\begin{array}{l}\text { (1) Small and Medium } \\
\text { Enterprise Development Plan } \\
\text { (2004-2010) (2) Micro, Small } \\
\text { and Medium Development } \\
\text { Plan (2011-2016) (3) } \\
\text { Philippine development Plan } \\
\text { (2011-2016) }\end{array}$ & $\begin{array}{l}\text { (1) The First SME Promotional Plan (2002- } \\
\text { 2006) (2011), (3)The Third SME Promotional } \\
\text { Strategic Plan and Action Plan by Sector } \\
\text { (2013), (5) Thailand Country Strategy (2012), } \\
\text { (6)Five year strategic Plan (central bank) 2012 }\end{array}$ \\
\hline
\end{tabular}

Source: Asia Development Bank. (2015). Asia. SME Finance Monitor 2014. Asian Development Bank.

On SMEs Policies and Financial Regulations regarding Capital (Table 5) could be seen that there is a complete similarity on all countries being the Security and Exchange Commission on the top of the situation.

In countries such as the Philippines, the average wages of workers in large firms might be three times higher than the average wages of workers in small firms. This large wage differential suggests that the productivity of smaller firms in thePhilippines is much lower than of its larger firms. Therefore, there is a large scope for increases in productivity of smaller firms which could lead to an improvement in the quantity of employment as well as the wages paid to the average worker. ${ }^{1}$

\section{Banking Sector}

Under the banking sector, Bangladesh is a leading country in micro-finance but there is still a lack of concrete data on SME financing as with the other two countries. While microfinance is promoted as an effective tool for poverty reduction, SME finance is seen as an instrument to realize sustainability, resilient economic growth. ${ }^{2}$

Bangladesh addresses it SME credit collections by the existence of support partners through institutes refinancing schemes. These schemes to refinance SME loans given by banks and NBFIs (Non Bank Financial Institutions) are (i) the new entrepreneur refinancing fund for the cottage, micro and small sector industries and (ii) the Islamic Shariah has developed refinanc-

\footnotetext{
1 Khor, Niny et al. (2013). Enterprises in the Philippines: Dynamism and Constraints to Employment Growth, ADB Economic Working Series, No. 334, Philippine, pp. 33-40 (Viewed on 1st January, 2017).

2 Asian Development Bank (2014b), ADB-OECD study on enhancing financial accessibility for SMEs: Lessons from recent crises, Philippines.
}

ing scheme for an Islamic bank. This first scheme would be accompanied by an interest of $10 \%$ to prospective loans of entrepreneurs with training. Islamic Banks are also trying to finance agrobased industries, non-farm activities and small entrepreneur at a local level in limited scale including creating an opportunity for generating employment However, the business of Islamic banking sector is not transparent as they are not doing progressive banking.

The Philippines has fallen short of its established targeted Micro and Small Enterprise since 2008. The reason behind is that some large banks opted to pay a fine rather than set aside funds for lending to risky borrowers. This was abridged by establishing simplified and standard lending procedures and guidelines for evaluating SMEs loans. Credit guarantee programs were provided by small business corporation and credit surety fund program of The Bangko Sentral ng Pilipinas (BSP) Finally, in 2012, the seventh largest Micro Financing Institutions (MFIs) formed a private credit Bureau known as Microfinance Data Sharing System (MiDAS) which allowed participating MFIs to submit reports, send inquiries, and retrieve information on borrowers. This would allow searching for delinquent borrowers. ${ }^{3}$

Thailand, however, has an increasing trend in SME credit: (i) SMEs' strong appetite for growth capital, (ii) banks' lending attitude shifting from large lot transactions with large firms to retail financing, and (iii) the portfolio guarantee scheme. The global financial crisis forced their large firms to take longer time for business recovery and encouraged banks to head for the retail market, addressing the SME demand. The portfolio guarantee scheme started in 2009 as part of the Thai

\footnotetext{
${ }^{3}$ Ibid.
} 
economic stimulus measure against the global financial crisis. ${ }^{1}$ A preventive measure in order to curtain any future loss from any global crisis should be taken.

In the banking sector, it could be seen that all countries have the problem of SMEs secured lending. Bangladesh showed the provision of refinancing schemes supporting by NGO partners and the recognition of opportunities to Women Entrepreneurs. But no remarkable achievement is yet to occur.

\section{Implementation of SDG (Sustainable development Goal) - 1, 5 and 8}

SDG 1 is relating to End poverty in all its forms everywhere, SDG-5 argues to achieve gender equality and empowerment of all women and girls while SDG- 8 deals with Decent Work and Economic Growth. [10]. Bangladesh is trying to develop a set of its own post-2015 sustainable development goals with associated targets and indicators, keeping the relevant ones, modified if and as necessary, from the adopted global agenda [24]. Bangladesh Federation of Women Entrepreneurs and Women Entrepreneur Association of Bangladesh do not support rural and urban slum dwellers in true sense to become a small entrepreneur.

Thailand provided a portfolio of sustainable credit guarantee system that would curtail future losses.

Women of Philippines on its side, offered a solution by creating a common bureau where reports are submitted and would control the problem of delinquent borrowers. Economic empowerment is a prerequisite for sustainable development and pro-poor growth. The Asia-Pacific region loses an estimated $\$ 89$ billion in income every year because women are underrepresented in the workforce. If women's representation increased to $70 \%$, as in the advanced economies, annual GDP could be $4.2 \%$ higher in India, $2.9 \%$ higher in Malaysia, and $1.4 \%$ higher in Indonesia. Women who gain equal access to education and economic decision-making are a key driving force against poverty through raising household incomes. The evidence shows that when women have greater control over resources, investment in children's health, education and nutrition increases, it leads to the long-term benefits for future generations. In South Asia, $60 \%$ of employed women work in family enterprises but do not get paid. In Thailand $-32 \%$, the Philippines $-47 \%$, Bangladesh $-97 \%$, the

${ }^{1}$ Ibid. average participation of women in the workforce remains low. ${ }^{2}$ But SDG- 5 stated clearly the need to achieve gender equality and empower all women and girls. Further SDG- 8 stated the need to promote sustained inclusive and sustainable economic growth, full and productive employment and decent work for all. To attain this larger role of international banking and finance, we need to work in a right direction without any sort of corruption. In the Philippines, to implement SDGs, a Roadmap-framework was prepared to guide government and other key stakeholders on the needed actions, resources, to build responsibilities of partnerships to the success SDG implementation. ${ }^{3}$

SDGs- 8 is to Promote Sustain, Inclusive and Sustainable Eco Growth, Full \& Productive Employment and Decent Work for all: Sustain per capita income (7\% for the LDCs), end child labor by 2025, protect labor rights; sustenance of per capita economic growth and productivity through diversification; technological upgrading and innovation; high value-added and labour intensive sectors; growth of micro and SME through access to finance. Strengthening the capacity of the domestic sector, to improve global resource efficiency in the consumption and production process progressively; quality of education and training should be improved. ${ }^{4}$ In Thailand, in line with the sustainable development goal, Gender Equality act 2015 - recognizes equality and sexual diversity. When changes in cultural values are slow in the making, this legislation sends a strong message to the public that the values which endorse discrimination are wrong and discriminatory practices are illegal. It sets a new standard for society to follow, so everyone can take part in sustainable development and benefits from it equally. In 2016, in Thailand, the government opened a national policy to strengthen public-private-people partnership to boost inter-sector collaboration and inclusive growth with an aim to strengthen local enterprises and promote decent work. ${ }^{5}$

\footnotetext{
2 Retrieved from: http://effectivecooperation.org/wp-content/ uploads/2016/11/RBAP-DG-2016-AP-DEF-Achieving-SDGs. pdf (date of access: 1st March, 2017).

${ }^{3}$ Retrieved from: https://sustainabledevelopment.un.org/content/documents/21391Philippines.pdf (date of access: 1st March, 2017).

4 Retrieved from: http://cpd.org.bd/wp-content/uploads /2016/10/Role-of-Private-Sector-in-SDGs-Implementation.pdf (date of access: 1st March, 2017).

Retrieved from:http://www.mfa.go.th/SEPforSDGs/ SEPThailandsPathtowardsSDGS/SEPThailandsPathtowards SDGs.pdf (date of access: 1st March, 2017).
} 


\section{Nonbanking Sector}

Bangladesh Nonbank Financial Institutions (NBFI) continues to narrow in comparison with banks in Bangladesh. NBFI outreached maybe limited as compared with banks however they offered certain products including factoring and lending to a greater extent than banks. This is proven by the Industrial Development and Leasing Corporation (IDLC) known as the largest NBFI in Bangladesh which received SME NBFI of the Year 2013 and Best Women-Friendly NBFI of the year 2013. IDLC had $38.2 \%$ of SME loans, $34.5 \%$ of consumer loans, $27.4 \%$ is corporate loans of Bangladesh. We observed that in case of geographically coverage in Bangladesh almost all NBFIs are urban-centric and they do not work properly in the hill tract areas and numbers of bank branches in the rural areas are very low. SMEs in urban areas are well served but the financial gap is greater in semi-urban and rural areas. ${ }^{1}$ Alternative banking system should be introduced by the government, namely Community banking as Ali found that it works well. This will help to act as financial intermediary between Micro savings and micro investment.

Micro-financing in Bangladesh continues to play with some short comings in providing finance to micro and small enterprises. The Micro Credit Regulatory Authority (MRA) regulates the operations of all micro institutions (MFIs) especially nongovernment-organization-funded MFIs and Grameen Bank. Comilla cooperative model is by far superior but lack of strategic leadership, it cannot currently work rather became gradually dyfunctional. In the Eight five year plan fresh inject of the Comilla cooperative should be taken to revitalize.

Loans provided below USD 60 are considered micro loans and loans between USD 600 to USD 0.012 million are considered micro enterprise loans. Most micro enterprise loans are repeater borrowers with good credit history. MFIs are not allowed to take collateral from borrowers but sanction loans based on group guarantees. Most Micro loans offer a maximum rate of $27 \%$ with 1-year loan terms with 46 installments.

In the Philippines, The Bangko Sentral ng Pilipinas (BSP) regulates and supervises 17,862 non-banking financial institutions (NBFIs).

NBFIs with quasi-banking function are regulated by BSP including pawnshops, non-stock savings, loan associations and electronic money

\footnotetext{
${ }^{1}$ Retrieved from: http://cpd.org.bd/wp-content/uploads/2016 /10/Role-of-Private-Sector-in-SDGs-Implementation.pdf (date of access: 1st March, 2017).
}

issuers. NBIFs without quasi-banking functions are regulated by the Security and Exchange Commission.

The existence of Micro Data Sharing System (MiDaS) by seven largest MFIs in 2012 allows MFIs to submit reports, send inquiries and retrieve results on borrower information. The system shares data on financially troubled clients to offer possible solutions to them.

Pawnshops as well are a viable source of funding and are accessible for the poor and the self-employed. Pawnshop extends loans only if they are secured by personal property that could be physically delivered to the control and possession of the pawnshop.

Thailand, on the other hand, had 1,884 savings cooperatives and credit unions, 556 pawnshops and 47 leasing companies operating in the country as of the end of 2016 . However, the assets of NBFIs to total financial institutions are quite small composing of $4.9 \%$ for savings, cooperatives and credit unions, $0.2 \%$ of pawnshops and $0.6 \%$ for leasing companies which are regulated by Security and exchange Commission.

In the area of the nonbank sector in Bangladesh, the impact of nonbank loans on SMEs is seen to be in the urban-centric areas limiting the development only within populated areas. A few could be seen in rural areas. In the Philippines, more reporting requirements has become tough to maintain a microdata sharing system. A sharing system requires distinguishing clients who are financially troubled and suggested a possiblesolution bring back the customer to its proper senses.

\section{Capital Markets}

In Bangladesh, Dhaka Stock Exchange (DSE) is the largest stock exchange while Chittagong Stock Exchange (CSE) is another stock exchange. Figure 3 is shown Trading at Dhaka Stock exchange from the year 1995 to 2017 at below. There are two capital market scam in the year 1996 and 2010-11 in Bangladesh.

However, in Bangladesh Capital market is not well equipped to finance MSMEs as they are largely depend on share market. Still debt market and derivatives markets were not developed in the country. Fiscal policy should be induced to improve capital market of the country. Keynes rightly pointed out that if capital market is in problem than monetary policy ought to help it.

In the Philippines, SEC mandated the corporate and capital market infrastructure of the Philippines. It is also mandated to encourage competitiveness in the market by promulgating rules for the registration and licensing of innova- 


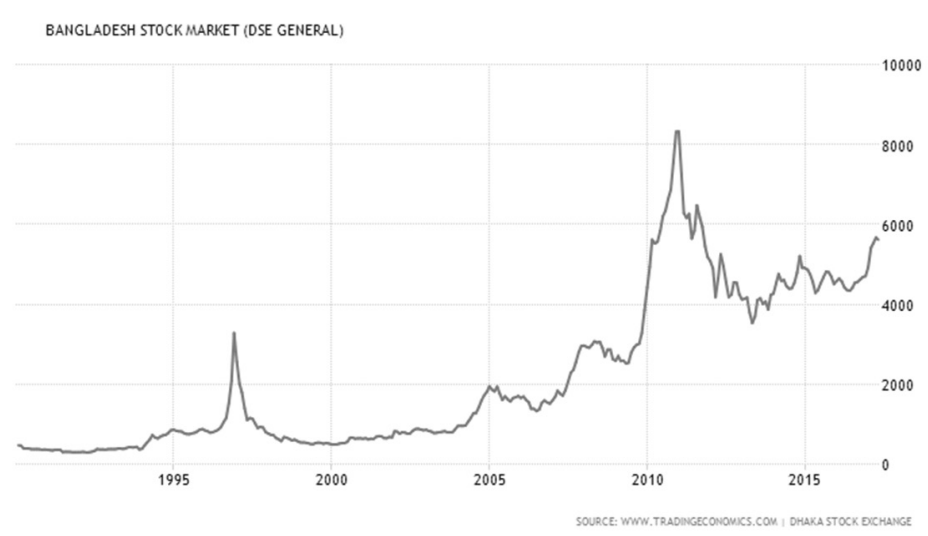

Fig. 3. Trading at Dhaka Stock exchange from the year 1995to 2017. Source: http://www.tradingeconomics.com/bangladesh/ stock-market (viewed on 27th April, 2017)

tive and other trading markets or exchanges, covering but not limited to the issuance of innovative securities and securities of SMEs and venture businesses.

In June 2013, the SEC approved the Philippine Stock Exchange (PSE) rules creating the twoboard system: The Small, Medium and Emerging Board and the Main Board. Companies applying for SME Board must have authorized capital stock of at least USD 2 million, of which at least $25 \%$ is subscribed and fully paid, a minimum of 200 stockholders upon listing, and USD 0.3 million cumulative earnings for the last three fiscal years. This gave the opportunity of SMEs to have access to bigger funds. Out of six companies who applied for bigger funds but two companies got bigger fund.

Further, a law creating and dedicating Small and Medium Enterprise Stock exchange intended to provide equity financing opportunities for growing businesses. It shall cater small enterprises with capital between USD .04 million and USD .38 million and medium-sized enterprises with capital between USD .4 million and USD 1.98 million in equity financing. ${ }^{1}$

The real impacts of a lack of access to finance also confirmed other studies asserting that access to finance has remained one of the most critical factors affecting the competitiveness of MSMES and the continual difficulties of Filipino MSMEs in accessing finance. ${ }^{2}$

Thailand, on the other hand, has Market for Alternative Investment (MAI) which was established under the Stock Exchange in 1998. Its aim

\footnotetext{
${ }^{1}$ Asian Development Bank (2014b), ADB-OECD study on enhancing financial accessibility for SMEs: Lessons from recent crises, Philippines.

${ }^{2}$ Khor, Niny et al. (2013). Enterprises in the Philippines: Dynamism and Constraints to Employment Growth, ADB Economic Working Series, No. 334, Philippine, pp. 33-40 (Viewed on 1st January, 2017).
}

is to provide opportunities for entrepreneurs and SMEs to tap long-term growth capital. As of December 2014, 109 companies are listed with a total turnover value of USD 11.37 billion and total turnover value of USD 24.91 billion. 18 companies have successfully moved from MAI to main board of the stock exchange. This indicates that MAI has become a preparatory venue for SME to tap the regular market of the stock exchange, and to lead them to the business growth cycle.

From three countries, it could be seen that the importance of SMEs participating in the capital markets would allow SMEs to get more funds are needed for long run investment in the small and medium enterprises, especially for manufacturing industries. The access to capital markets would make move towards SMEs from a big company traded on the big board.

\section{Discussions, Conclusions and Implications}

The major activities of SME Foundation are the implementation of SME Policy Strategies adopted by the Bangladesh Government, policy advocacy and intervention for the growth of SMEs, facilitating financial supports for SMEs, providing skill development and capacity building training, facilitating adaptation with appropriate technologies and access to ICT, providing business support services, etc. It has been mentioned that the Foundation is working for the development of enterprises and entrepreneurs who belong to micro, small and medium categories as per Industrial Policy 2010. Besides the general support to the development of SMEs and entrepreneurs, the Foundation is providing diversified support to the existing and potential women entrepreneurs in order to position them into the mainstream business community. ${ }^{3}$ Three factors to be noted for ex-

\footnotetext{
Retrieved from: http://www.smef.org.bd/v2/index. php?popup_anywhere_preview=true (date of access: 10
} 
pediting MSMEs (Micro, Small and Medium enterprises) in informal sector: the larger the informal sector in an economy, the lower the formal MSME density; In economies where it is more costly to start or close a formal business, the density of formal MSMEs is lower; Corruption is negatively associated with MSME density, as evidenced by lower MSME density in countries where firms are more frequently asked to make informal payments (bribes) to government officials. ${ }^{1}$ Light engineering of Bangladesh is the capital-intensive industry. Due to the lack of capital, small manufacturing enterprises dominate in the sector. These are scattered throughout the country in various clusters. Light engineering enterprises proliferated through skilled workers coming out of pioneering enterprises, which created some well-known clusters (Dhaka and Bogra) in several geographical regions. Dholaikhal Dhaka light engineering cluster comprises of 5,000 engineering units. These engineering firms produce only solid waste. Due to discharging solid waste, these engineering firms belong to the green category as per country's environmental regulation. Green category manufacturing firms are, by and large, free from environmental hazards. ${ }^{2}$ Government of Bangladesh should recognize the contribution of Dholaikhal as a major area of a formal sector of SMEs and give a scope for inclusion process in the main economic stream.

In future, a comparative study may be done through collecting primary data of these three countries which need time and money as well as patronization from any independent organization. In addition, a separate study may be done on the role of the Formal and informal sector at SMEs and their business processes. The effectiveness of removal of gender biasness, empowerment of people and sustainable development through SMEs can be investigated in future. Further, those who received foreign donations/grants/loans in the private sector to develop women entrepreneurs through their institutions should be surveyed to assess that they comply with all the terms and regulations to help marginalized and pauperized women as well men group.

Creation, innovation, development and viable sustainability of SMEs is a key to meet the changing demands of Globalization. Each country has

\footnotetext{
Novemebr, 2017).

1 Retrieved from: https://smefinanceforum.org/sites/default/ files/analysis_note_2010.pdf (date of access: 5th February, 2017).

${ }^{2}$ Retrieved from: http://euinspired.org.bd/docs/grant_scheme/ INSPIRED \% 20-\%20Light\%20Engineering $\% 20$ Sector $\% 20$ Report\%20-\%20Jan\%20'13.pdf (date of access: 1st March 2017).
}

its own strengths that the other countries could benchmark and innovate. Each country may have the same problematic area to solve but solved differently. The financial market should be prone to SMEs so that it can help to achieve some targets of sustainable development goals. The informal sector still plays a vital role. SMEs should be used in the transformation process to the formal sector so that it helps for financial inclusion and creation of empowerment of human being. International labor Organization (ILO) study suggested that well-designed policies can facilitate transitions to formality and promote productive employment effectively in the formal economy in a manner that provides new opportunities for all workers and economic units, including opportunities to move to the formal economy. ${ }^{3}$

The analysis of Bangladesh, the Philippines and Thailand has given to the researchers the following conclusions: First, data submitted to Development Banks must be of the same category and classification for the furtherance of Development in Asia. Second, SMEs should be supported by an agency, a concrete law and policies that need to be constantly updated with changing demands. Third, need to create fall back schemes against SMEs lending. Fourth, the need to deliver SMEs services not only within the urban areas but also within the sub-urban and rural areas. Requirements for SME sector to get additional funds through the use of not only loans but through the use of the capital market. Fifth, SMEs should work systematically in the formal sector for which financial inclusion should be strengthened. Sixth, corporate governance among those who receive the fund of creating women entrepreneur in the name of Chamber/ Federation but does not have any documentation may be brought under the exiting rule of law of these three countries.

Moreover, SMEs should work to implement SDG-1, 5 and 8.SDG- 1 is referring to eliminate extreme poverty which requires a significant change of the country. This can be handled in a better fashion if cooperation within the countries and among the countries both regionally, bilaterally and transnational can be arranged through both private, public and foreign collaboration. As such integrating implementation of all Goals of SDG required to be fulfilled for which a special task force in collaboration among public, private sector, academic and research alliances, financial institutions etc. are required to be established.

\footnotetext{
Retrieved from: http://www.ilo.org/wcmsp5/groups/public/---ed_norm/---relconf/documents/meetingdocument/ wcms_218128.pdf (date of access: 1st March, 2017).
} 
It is further recommended that the educational institutions can be the forefront of educating the younger generation on the importance of SMEs where the focus would be creating entrepreneurship which will give them self-esteem, self-identity, self-dignity and even comply with the requirements of the job market. In addition, advocacy on the importance of engaging the young in the vehicles of savings and loans in the economy would increase the development of a countries economy. Micro savings may be arranged through alternative channels to current banking channels and creation of social capital and investment at micro level can be arranged through crafting community banking system under separate regulatory authority which may be accepted by the government of these countries. Comilla cooperative model should be revitalized with corruption free and changing the structure and to accelerate inclusive growth of the country. Grameen Bank also need to restructure starting form top management level towards downward as well as raising loan ceiling system and improving repayment system with lowering the interest rate. As such in the Managing Director position as well as in the Chairman Position two renowned economists should be appointed urgently for the greater shake of the poor people. When SMEs can be brought in a greater way in the formal sector from informal sector than safety of the job of the employees can be raised as well as govt. can earn more direct revenues.
Under the BIMSTEC regional cooperation, Thailand and Bangladesh can help each other in a collaborative effort on SMEs sector. This will be beneficial as it may add value in the domestic, regional and global value chain. The Philippines may also think to join the regional organization like BIMSTEC for strategic alliances. However, Bangladesh Bank fraudulent money which went to the Philippines as per international norms and rules they should return which will help both the country to have more congenial atmosphere. External and domestic linkage need to work as complementary to expand the business process with a competitive advantage and long run sustainability so that competitive advantage can be attained. Accelerating growth is needed to be emphasized. Bangladesh Govt. should set up community banking under arranging a new regulatory body for successful implementation of social capital by depositing micro savings of the lower income group and to transform it as micro investment through accelerating and multiplier impact so that financial inclusion can help to raise growth. Aforesaid recommendation is to set up community banking can also be followed in the Philippine and Thailand for transforming from informal sector to formal sector and gradually SME sector should be a part of mainstream business and employment opportunities of the formal sector.

\section{References}

1. Wanida, W. (2015). The Japanese and local partner relationship on Small and Medium enterprises (SMEs) and International Joint ventures (IJVs). Performance in Thailand Industrial sectors. Journal of Economic Cooperation and Development, 36(4), 1-24.

2. Watson, J. (2010). SME Performance: Separating Myth from Reality. Edward Elgar Publishing.

3. Gibson, T. \& Vander Vaart, H. J. (2008). Defining SMEs. A less imperfect way of defining Small and Medium Enterprises in Developing Countries. Brookings Global Economy and Development, 1-29.

4. Moazzem, K. G. (2006, September). Meeting the Challenges in SME Development in Bangladesh: Special Reference to Government's Budgetary Measures. KATALYST Bangladesh, p-30.

5. Hallberg, K. (2000). A Market-Oriented Strategy for Small and Medium Scale Enterprise. World Bank and International Finance Corporation, 22-23

6. Khan, E. A., Khan, M. S. \& Md, N. A. (2005). Factors Affecting the Growth of Entrepreneurship in Small-Scale Business. Business Review, 5(1), 33-37.

7. Susman, G. I. (2007). Small and Medium-sized Enterprises and the Global Economy. Edward Elgar Publishing, 1-10.

8. Mohiudddin, M. et al. (2 007). Entrepreneurship Development. MBA Program. School of Business. Bangladesh Open University, 343.

9. Tambunan, T. (2008, April). Development of SME in ASEAN with Reference to Indonesia and Thailand. Chulalongkorn Journal of Economics, 20(1), 53-83.

10. Ali, M. M. (2017). Socio-Economic Development of Bangladesh: Sustainability of BNF's partner organizations and Beneficiaries, MTC Global. India, 9-77.

11. Raffiee, J. \& Feng, J. (2014). Should I quit my day job? A Hybrid path to Entrepreneurship. Academy of Management Journal, 57(4), 936-963.

12. Hisrich, R. D. \& Peter, M. (2002). Entrepreneurship, 5th ed. Tata McGrawhill Publishing Company Ltd., India.

13. Hoque, M. Z. (2004). Industrial Loan Default - The case of Bangladesh. The University Press Ltd., Dhaka, Bangladesh, $8-21$. 
14. Habaradas, R. B. (2009). The challenges of SME innovation and technology upgrading in developing economies: insights from Malaysia, Thailand, and the Philippines. Journal of International Business Research, 8(1).

15. Moreno-Monroy, A. I. et al. (2014). Formal sector subcontracting and informal sector employment in Indian manufacturing. IZA Journal of Labor \& Development, 3(1), 1. Springer. DOI: 10.1186/s40175-014-0022-2.

16. Rattanawiboonsom, V. \& Ali, M. M. (2016). Factors affecting entrepreneurial management in Bangladesh: an empirical analysis. Student Ways, Dhaka, Bangladesh.

17. Watson, J. (2010). SME Performance: Separating Myth from Reality. Edward Elgar Publishing, 3-153.

18. Hampel-Milagrosa, Aimée (2014). Micro and Small Enterprise Upgrading in the Philippines: The role of the entrepreneur, enterprise, networks and business environment, Deutsches Institut für Entwicklungspolitik gGmbH, Bonn, pp. 9-14.

19. Sheng, A., Chow, S. N. \& Edelmann, C. Asia Finance 2020. Framing a New Asian Financial Architecture. Oliver Wyman Fund Global Institute, p. 18.

20. Woolley, J. L. (2014). The Creation and Configuration of Infrastructure for Entrepreneurship in Emerging Domains of Activity. Entrepreneurship Theory and Practice, 38(4), 721-747. DOI: 10.1111/etap.12017.

21. Ahmad, Q. K. (2004). Development of Whom for Whom by Whom. Mowla Brothers, Dhaka, 10-334.

22. Baimai, C. \& Mukherji, A. (2015). International entrepreneurial culture of Thai SMEs. Journal of Global Entrepreneurship Research, 5, 1-20. DOI: 10.1186/s40497-015-0041-8.

23. Roxas, B. \& Chadee, D. (2016, November). Knowledge management view of environmental sustainability in manufacturing SMEs in the Philippines. Knowledge Management Research \& Practice, 14(4), 514-524. DOI:10.1057/kmrp.2015.30.

24. Ahmad, Q. K. (2014). Sustainable development: Bangladesh Perspective. Asia Pacific Journal on Environment and Development, 22, 23, 81-90.

\section{Authors}

Muhammad Mahboob Ali - PhD in Social Sciences, Post Doctorate, Professor, Dhaka School of Economics (Economic Association Building, 4/C Eskaton Garden Road,Ramna, Dhaka1000, Bangladesh; e-mail:pipulbd@gmail.com).

Vichayanan Rattanawiboonsom - PhD in Mangment, Assistant Professor, Faculty of Business, Economics and Communications, Naresuan University (Thaplo, Muang, Phitsanuloke 65000, Thailand; e-mail: vichayananr@nu.ac.th).

Candido M. Perez - PhD in Business, Professor, College of Business and Accountancy, Lyceum of the Philippines University (Laguna, Philippines; e-mail: candido_perez@lpulaguna.edu.com/candidomperez@yahoo.com).

Abdullah Abusayed Khan - PhD in Social Sciences, Associate Professor, Department of Sociology, Khulna University (Bangladesh; e-mail:khanbdnks@yahoo.com). 